\title{
Greater Survival Improvement in African American vs. Caucasian Women with Hormone Negative Breast Cancer
}

\author{
Robert Wieder ${ }^{1,2}{ }^{\varpi}$, Basit Shafiq ${ }^{3,4}$ and Nabil Adam ${ }^{1,3,5}$ \\ 1. Department of Medicine, Rutgers New Jersey Medical School, Rutgers Biomedical and Health Sciences \\ 2. The Cancer Institute of New Jersey, Rutgers Biomedical and Health Sciences \\ 3. Institute of Data Science, Learning, and Applications (I-DSLA), Rutgers University Newark \\ 4. Department of Computer Science, Lahore University of Management Sciences (LUMS) \\ 5. Department of Management Science and Information Systems, Rutgers Business School
}

$\triangle$ Corresponding author: Robert Wieder, MD, PhD, Rutgers New Jersey Medical School, 205 South Orange Avenue, Cancer Center H1216, Newark, NJ 07103. Tel. 973-972-4871; Fax. 973-972-2668; E-mail. wiederro@njms.rutgers.edu

(c) The author(s). This is an open access article distributed under the terms of the Creative Commons Attribution License (https://creativecommons.org/licenses/by/4.0/). See http://ivyspring.com/terms for full terms and conditions.

Received: 2019.08.06; Accepted: 2019.10.30; Published: 2020.02.21

\begin{abstract}
Background: African American women have not benefited equally from recently improved breast cancer survival. We investigated if this was true for all subsets.

Methods: We identified 395,170 patients with breast adenocarcinoma from the SEER database from 1990 to 2011 with designated race, age, stage, grade, ER and PR status, marital status and laterality, as control. We grouped patients into two time periods, 1990-2000 and 2001-2011, three age categories, under 40, 40-69 and $\geq 70$ years and two stage categories, I-III and IV. We used the Kaplan-Meier and logrank tests to compare survival curves. We stratified data by patient- and tumor-associated variables to determine co-variation among confounding factors using the Pearson Chi-square test and Cox proportional hazards regression to determine hazard ratios (HR) to compare survival.

Results: Stage I-III patients of both races $\geq 70$ years old, African American widowed patients and Caucasians with ER- and PR- tumors had worse improvements in survival in 2001-2011 than younger, married or hormone receptor positive patients, respectively. In contrast, African Americans with ER(Cox HR 0.70 [95\% Cl 0.65-0.76]) and PR- (Cox HR 0.67 [95\% Cl 0.62-0.72]) had greater improvement in survival in 2001-2011 than Caucasians with ER- (Cox HR 0.81 [95\% Cl 0.78-0.84]) and PR-disease (Cox HR 0.75 [95\% Cl 0.73-0.78]). This was not associated with changes in distribution of tumor or patient attributes.

Conclusions: African American women with stage I-III ER- and PR- breast cancer had greater improvement in survival than Caucasians in 2001-2011. This is the first report of an improvement in racial disparities in survival from breast cancer in a subset of patients.
\end{abstract}

Key words: breast cancer, African Americans, risk factor, survival

\section{Background}

African American women have a lower incidence (1) but a persistently higher mortality from breast cancer than Caucasians (1-6). Spectrums of well documented patient-associated and tumorassociated variables have contributed to this disparity (7-21). African Americans are diagnosed at a younger age (19), higher stage $(22,23)$, higher grade $(24)$, have a higher frequency of ER- and PR- tumors $(22,25,26)$ and are more likely to be single than Caucasians (18, 22). All of these factors co-vary (21). In addition, well documented treatment-related disparities that include time to surgery, standard of care radiation, chemotherapy and social disadvantages (27) endow a worse prognosis in African American women than in Caucasian women with breast cancer. 
Although overall mortality rates have declined in the last three decades, African American women did not benefit from this decline equally with Caucasians (1, 28-35). However, while population-averaged trends depict a uniform picture of unrelenting or progressively disparate outcomes, they systematically hide the impact of opposite trends, should they occur in population sub-segments (21). In one example, African American women with regional disease appeared to have superior increases in survival than Caucasians between the 1970s and 1990s, while no differences were evident in the unparsed population (1). In a study of the Surveillance, Epidemiology and End Results (SEER) data, the percentage increases in one-, three- and five-year survival of women diagnosed with all forms of breast cancer between the period 2004-2009 compared to the survival of patients diagnosed in the period 2001-2003 appeared to be consistently greater in African American women than in Caucasian women (36). Five-year age standardized survival for all stages combined also increased more between these two time periods for African American women than for Caucasian women (36). In another SEER study, when comparing the annual hazard rates for death in the two to seven years after initial diagnosis of women with locoregional ER- and to a lesser extent, ER+ breast cancer, decreases in the period 1997-2004 compared to those in the period 1990-1994 appeared to occur at a greater rate in African American women than in Caucasian women (37). Despite the apparent narrowing of differences in survival in patient subsets, disparities in the combined population persisted and continued to be reported. Although these studies did not address nor provide statistical treatment of the data, they nevertheless presented evidence that suggests that a greater improvement in survival may have occurred among some African American women with breast cancer than in Caucasian women.

Here, we undertake a formal investigation and focus on testing the hypothesis that African American women with locoregional ER- and PR- breast cancer had a greater improvement in survival after the turn of the century than their Caucasian counterparts. Stratification by ER and PR status is relevant, as it differentiates breast cancer categories of different cellular origin, biology, response to therapy, relapse pattern, prognosis and frequency in African American patients (21). We present the possibility that improvements in breast cancer survival have begun to chip away at racial disparities at least in one breast cancer category. We use the SEER database to stratify the population and compare patient survival Cox proportional hazard ratios (HR) between the two races while controlling for tumor and patient characteristics annotated in the SEER database.

\section{Methods}

\section{Data and Patients}

We analyzed the SEER database of the National Cancer Institute (38) from 1973 to 2011 (SEER database) for female patients with ICD-O-3 diagnostic codes for adenocarcinoma of the breast, as before (21), yielding 1,307,298 cases. The study was approved by the Rutgers Biomedical and Health Sciences Institutional Review Board-Newark.

We considered patients with race designated as White or Caucasian and Black or African American (21). We restricted the dataset analysis to newly diagnosed patients with stages I, II and III and patients who were classified as stage IV or recurrent, those with clear designations of tumor grades 1,2 or 3 , estrogen receptor status as positive (ER+) or negative (ER-), progesterone receptor status as positive ( $\mathrm{PR}+$ ) or negative (PR-), age, marital status as single, married, separated, divorced or widowed, and breast cancer laterality as right or left. For our analysis, we grouped ages into three categories, under 40 years, $40-69$ years and $\geq 70$ years, to roughly correspond to earlier age patients who get breast cancer less frequently, have more aggressive tumors and who do not have recommendations to receive population screening, to the population for whom screening is recommended by various organizations, and the older population for whom screening is not recommended and who tend to have less aggressive disease, respecttively. We analyzed 395,170 patients who were diagnosed between 1990 and 2011, because the database did not include ER and PR status before 1990.

\section{Statistical Analysis}

We analyzed data from two time periods, 1990-2000 and 2001-2011. We defined survival in months as time from diagnosis of stage I, II or III breast cancer or from initial diagnosis of recurrence or presentation with metastatic disease to the time of death from any cause within the decade of analysis, since the cause of death in the SEER database is frequently listed as due to an immediate physiologic event and often not attributed to the underlying cause of breast cancer. Patients alive on December 31, 2000 and December 31, 2011 in the two analytic periods, respectively, were included in the analysis up to the respective periods' cut-off date and were censored from subsequent analysis.

We used the Kaplan-Meier method to generate survival curves and used the logrank test to compare the curves (39). We used Cox proportional hazards regression analysis to determine hazard ratios to 
compare survival. The predictor variables were the time periods between 1990 and 2000 and between 2001 and 2011, with the earlier decade as the base group. We stratified the data by race, age (in the three categories described above), stage, grade, ER status, PR status, marital status, and laterality as a negative control, and determined co-variation among these confounding factors using the Pearson Chi-square test. A p-value less than or equal to 0.05 was considered statistically significant. We computed estimates of Cox hazard ratios (HR) and associated 95\% confidence intervals for each stratification from the 2001-2011 period versus the 1990-2000 period using the Cox proportional hazards regression model. All statistical analyses were performed using $R$ Version 3.1.1 and R Studio Version 0.98.1056 (The R Foundation, Vienna, Austria) statistical software.

A major assumption of the Cox proportional hazards regression model is that the effect of a given covariate does not change over time, i.e., the hazards ratio remains constant over time $(40,41)$. To test if the proportional hazards assumption holds, we performed Schoenfeld residuals analysis. Nonproportionality of hazards is evidenced by the presence of a linear relationship of the Schoenfeld residuals against time (40). This linear relationship is tested by performing linear regression and determining the statistical significance of the regression coefficients based on their p-values. A p-value $>0.05$ indicates a random pattern of residuals with time, implying that the proportional hazards assumption holds.

\section{Results}

We compared the patient populations with stage I-III cancer and stage IV cancer to confirm that our data were similar to what is known about the characteristics of the two categories. A total of $95.9 \%$ of patients had localized disease and $4.1 \%$ had recurrent or metastatic disease. Median follow up for the periods 1990-2000 and 2001-2011 was 35 months and 51 months for stage I-III patients and 13 months and 19 months for stage IV patients, respectively.

All patient-associated and tumor-associated variables assessed had significantly different distributions in the two patient groups (Table 1). The stage IV group had higher proportions of patients who were African American, under 40, 70 or older, single or widowed than the stage I-III group. Patients in the stage IV group had higher frequency of tumors that were grade 3, ER- or PR- than patients in the stage I-III group. Laterality, which was included as a negative control, was not different between the two groups.

We compared data from the two time periods straddling the turn of the century, 1990-2000 and
2001-2011. This provided a platform for analysis in the context of recent reports of improved survival from breast cancer (33-35). Figures 1A and 1B depict Kaplan-Meier survival curves using logrank tests demonstrating significant improvements in Cox HR in the 2001-2011 time periods for Caucasians and for African Americans in both the stage I-III and stage IV groupings. Of note, the probability of survival of Caucasians continued to be better than that of African Americans. None of the groups with stage I-III disease reached median survival by 132 months after diagnosis in either decade. For stage IV patients, the median survival was 23 and 17 months in the 1990-2000 time period and 34 and 22 months in the 2001-2011 time period for Caucasians and African Americans, respectively.

Table 1. Differences in the distribution of patient- and tumor-associated factors between stage I-III and stage IV breast cancer

\begin{tabular}{|c|c|c|c|c|c|}
\hline \multirow[t]{2}{*}{$\begin{array}{l}\text { Total Number } \\
\text { stratified }\end{array}$} & \multicolumn{2}{|c|}{$\begin{array}{l}\text { Stage I-III } \\
379,052\end{array}$} & \multicolumn{2}{|l|}{$\begin{array}{l}\text { Stage IV } \\
16,118\end{array}$} & \multirow{2}{*}{$\begin{array}{l}P \\
\text { (Chi } \\
- \text { square) }\end{array}$} \\
\hline & Number & $\%$ in category & Number & $\%$ in category & \\
\hline \multicolumn{6}{|l|}{ Race } \\
\hline Caucasian & 340,644 & 89.9 & 13,434 & 83.3 & $<.001$ \\
\hline African American & 38,408 & 10.1 & 2,684 & 16.7 & \\
\hline \multicolumn{6}{|l|}{ Age grouping } \\
\hline$<40$ & 23,257 & 6.1 & 1,116 & 6.9 & $<.001$ \\
\hline $40-69$ & 257,169 & 67.9 & 10,320 & 64.0 & \\
\hline$\geq 70$ & 98,626 & 26.0 & 4,682 & 29.0 & \\
\hline \multicolumn{6}{|l|}{ Grade } \\
\hline 1 & 72,103 & 19.0 & 1,051 & 6.5 & $<.001$ \\
\hline 2 & 162,700 & 42,9 & 6,335 & 39.3 & \\
\hline 3 & 144,249 & 38.1 & 8,732 & 54.2 & \\
\hline \multicolumn{6}{|l|}{ ER Status } \\
\hline+ & 296,814 & 78.3 & 11,490 & 71.3 & $<.001$ \\
\hline- & 82,238 & 21.7 & 4,628 & 28.7 & \\
\hline \multicolumn{6}{|l|}{ PR Status } \\
\hline+ & 257,815 & 68.0 & 9,289 & 57.6 & $<.001$ \\
\hline- & 121,237 & 32.0 & 6,829 & 42.4 & \\
\hline \multicolumn{6}{|l|}{ Marital Status } \\
\hline Single & 49,219 & 13.0 & 3.101 & 19.2 & $<.001$ \\
\hline Married & 224,023 & 59.1 & 7,587 & 47.1 & \\
\hline Separated & 3,567 & 0.9 & 222 & 1.4 & \\
\hline Divorced & 41,855 & 11.0 & 2,041 & 12.7 & \\
\hline Widowed & 60,388 & 15.9 & 3,167 & 19.6 & \\
\hline \multicolumn{6}{|l|}{ Laterality } \\
\hline Right & 186,765 & 49.3 & 7,892 & 49.0 & 0.44 \\
\hline Left & 192,287 & 50.7 & 8,226 & 51.0 & \\
\hline
\end{tabular}

To obtain added insight into differences in survival revealed by the Kaplan-Meier curves and the logrank test, we determined differences in distributions of patient- and tumor-associated characteristics between the two time periods for both stage I-III and stage IV patients using Chi square analysis. Table 2 demonstrates significant differences in the distribution of both patient- and tumor-associated factors in the two time periods. Patients of African American race, patients between 40-69 and patients who were single were more 
frequently represented, while patients 70 and older and widows were less represented in the years 2001-2011 in both the stage I-III and stage IV categories. The frequency of grade 3 tumors also decreased in patients with localized and stage IV disease in the latter decade. Patients with stage III, ER- and PR- tumors decreased in the group with localized disease, but the frequency of ER-tumors did not change significantly and PR-tumors increased in stage IV patients in the years 2001-2011. There were no significant differences in the control variable of laterality. Given the significant changes in distribution of both patient- and tumor-associated characteristics in the two time periods, we reanalyzed survival differences using Cox proportional hazard ratios. While we found significant improvements in the Cox HR for survival in the latter decade in the unparsed populations of Caucasian and African American breast cancer patients and in all of the subpopulations stratified by various patient- and tumor-associated variables (Table 3), in most of these cases the proportional hazards assumption did not hold as reflected by the Schoenfeld residuals $p$-value $<0.05$. Only in the case of Caucasians with Stage I (Cox HR 0.78 [95\% confidence intervals 0.75 - 0.81]) and Stage IV disease (Cox HR 0.72 [95\% confidence intervals $0.68-0.76]$ ), African Americans with Stage I (Cox HR 0.71 [95\% confidence intervals 0.63 - 0.81]), Stage II (Cox HR 0.73 [95\% confidence intervals 0.67 0.79]) and Stage III disease (Cox HR 0.70 [95\% confidence intervals $0.64-0.76]$ ), patients in the $<40$ years category (Cox HR 0.70 [95\% confidence intervals $0.65-0.76]$ ), patients with grade 1 tumors (Cox HR 0.80 [95\% confidence intervals $0.75-0.85]$ ) and patients in the Married (Cox HR 0.71 [95\% confidence intervals 0.69 - 0.73]) and Divorced categories (Cox HR 0.84 [95\% confidence intervals 0.79 - 0.89]) were the improvements in survival between the decades significant. There were also some notable differences between the extent of improvement in survival, specifically between Caucasian women with Stage II disease and Caucasians in the all stage category, women aged $>70$ and those in the other two age categories, Widowed women compared to Married or Divorced women and women with ER- and PRtumors and patients with ER+ and PR+ tumors, respectively, but the linearity of the Schoenfeld residuals showed that the proportional hazards assumption did not hold. To remove the problem of nonproportionality (40), we further stratified the data.

Table 2. Differences in the distribution of patient- and tumor-associated factors between the years 1990-2000 and 2001-2011 in patients with stage I-III and stage IV breast cancer

\begin{tabular}{|c|c|c|c|c|c|c|c|c|c|c|}
\hline \multirow[t]{4}{*}{ Number stratified } & \multicolumn{5}{|c|}{ Stages I-III } & \multicolumn{5}{|l|}{ Stage IV } \\
\hline & \multirow{2}{*}{\multicolumn{2}{|c|}{$\begin{array}{l}1990-2000 \\
92,637\end{array}$}} & \multirow{2}{*}{\multicolumn{2}{|c|}{$\begin{array}{l}2001-2011 \\
286,415\end{array}$}} & \multirow{3}{*}{$\begin{array}{l}P(\text { Chi } \\
\text { square) }\end{array}$} & \multirow{2}{*}{\multicolumn{2}{|c|}{$\begin{array}{l}1990-2000 \\
2,891\end{array}$}} & \multirow{2}{*}{\multicolumn{2}{|c|}{$\begin{array}{l}2001-2011 \\
13,227\end{array}$}} & \multirow{3}{*}{$\begin{array}{l}P(\text { Chi } \\
\text { square }\end{array}$} \\
\hline & & & & & & & & & & \\
\hline & Number & $\%$ in category & Number & $\%$ in category & & Number & $\%$ in category & Number & $\%$ in category & \\
\hline \multicolumn{11}{|l|}{ Race } \\
\hline Caucasian & 84,947 & 91.7 & 255,697 & 89.3 & \multirow[t]{2}{*}{$<.001$} & 2,506 & 86.7 & 10,928 & 82.6 & \multirow[t]{2}{*}{$<.001$} \\
\hline African American & 7,690 & 8.3 & 30,718 & 10.7 & & 385 & 13.3 & 2,299 & 17.4 & \\
\hline \multicolumn{11}{|l|}{ Age grouping } \\
\hline$<40$ & 6,323 & 6.8 & 16,934 & 5.9 & \multirow[t]{3}{*}{$<.001$} & 186 & 6.4 & 930 & 7.0 & \multirow[t]{3}{*}{$<.001$} \\
\hline $40-69$ & 59,780 & 64.5 & 197,389 & 68.9 & & 1,732 & 59.9 & 8,588 & 64.9 & \\
\hline$>70$ & 26,534 & 28.6 & 72,092 & 25.2 & & 973 & 33.7 & 3,709 & 28.0 & \\
\hline \multicolumn{11}{|l|}{ Stage } \\
\hline I & 45,598 & 49.2 & 143,627 & 50.2 & \multirow[t]{3}{*}{$<.001$} & & & & & \\
\hline II & 33,208 & 35.9 & 105,487 & 36.8 & & & & & & \\
\hline III & 13,831 & 14.9 & 37,301 & 13.0 & & & & & & \\
\hline \multicolumn{11}{|l|}{ Grade } \\
\hline 1 & 14,526 & 15.7 & 57,577 & 20.1 & \multirow[t]{3}{*}{$<.001$} & 150 & 5.2 & 901 & 6.8 & \multirow[t]{3}{*}{$<.001$} \\
\hline 2 & 41,011 & 44.3 & 121,689 & 42.5 & & 1,032 & 35.7 & 5,303 & 40.1 & \\
\hline 3 & 37,100 & 40.0 & 107,149 & 37.4 & & 1,709 & 59.1 & 7,023 & 53.1 & \\
\hline \multicolumn{11}{|l|}{ ER Status } \\
\hline+ & 71,075 & 76.7 & 225,739 & 78.8 & \multirow[t]{2}{*}{$<.001$} & 2,063 & 71.4 & 9,427 & 71.3 & \multirow[t]{2}{*}{0.92} \\
\hline- & 21,562 & 23.3 & 60,676 & 21.2 & & 828 & 28.6 & 3,800 & 28.7 & \\
\hline \multicolumn{11}{|l|}{ PR Status } \\
\hline+ & 62,476 & 67.4 & 195,339 & 68.2 & \multirow[t]{2}{*}{$<.001$} & 1,725 & 59.7 & 7,564 & 57.2 & \multirow[t]{2}{*}{0.01} \\
\hline- & 30,161 & 32.6 & 91,076 & 31.8 & & 1,166 & 40.3 & 5,663 & 42.8 & \\
\hline \multicolumn{11}{|l|}{ Marital Status } \\
\hline Single & 10,407 & 11.2 & 38,812 & 13.6 & $<.001$ & 441 & 15.3 & 2,660 & 20.1 & $<.001$ \\
\hline Married & 54,819 & 59.2 & 169,204 & 59.1 & & 1,376 & 47.6 & 6,211 & 47.0 & \\
\hline Separated & 591 & 0.6 & 2,976 & 1.0 & & 20 & 0.7 & 202 & 1.5 & \\
\hline Divorced & 9,575 & 10.3 & 32,280 & 11.3 & & 318 & 11.0 & 1,723 & 13.0 & \\
\hline Widowed & 17,245 & 18.6 & 43,143 & 15.1 & & 736 & 25.4 & 2,431 & 18.4 & \\
\hline Laterality & & & & & & & & & & \\
\hline Right & 45,394 & 49.0 & 141,371 & 49.4 & 0.06 & 1,439 & 49.8 & 6,453 & 48.8 & 0.33 \\
\hline Left & 47,243 & 51.0 & 145,044 & 50.6 & & 1,452 & 50.2 & 6,774 & 51.2 & \\
\hline
\end{tabular}


A. Stage |-|I|

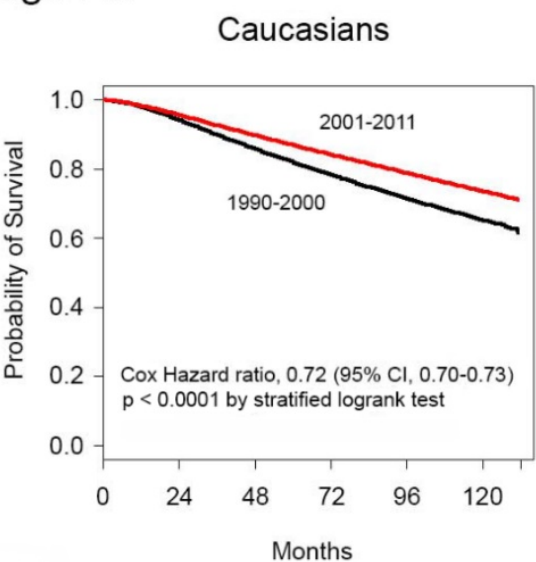

Number at risk

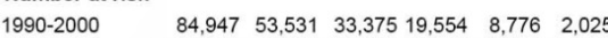
2001-2011 255,697 195,284 137,627 88,607 46,713 14,515

\section{B. Stage IV}

\section{Caucasians}

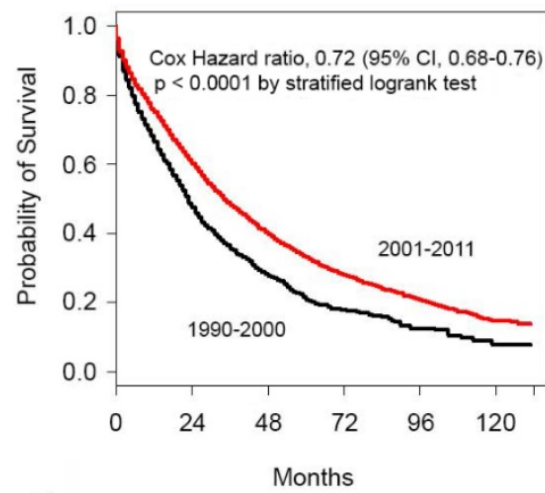

Number at risk

$\begin{array}{rrrrrrc}1990-2000 & 2,506 & 808 & 292 & 107 & \begin{array}{c}42 \\ (93 \text { mos. })\end{array} & \begin{array}{c}8 \\ (119 \text { mos. })\end{array} \\ 2001-2011 & 10,928 & 4,982 & 2,210 & 936 & 341 & 88\end{array}$

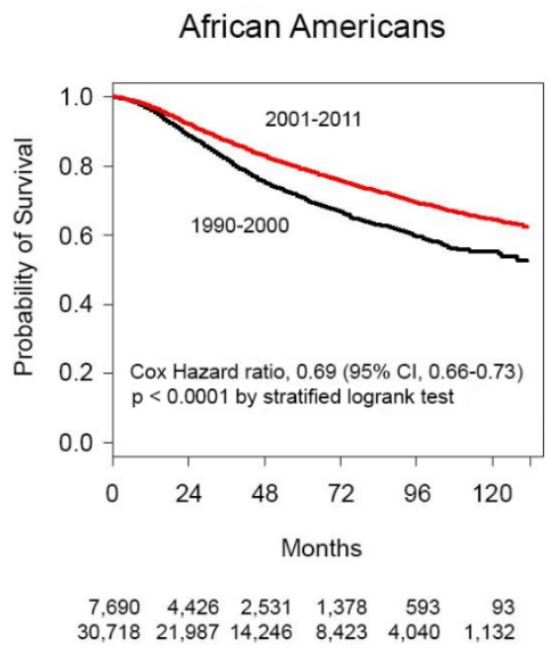

African Americans

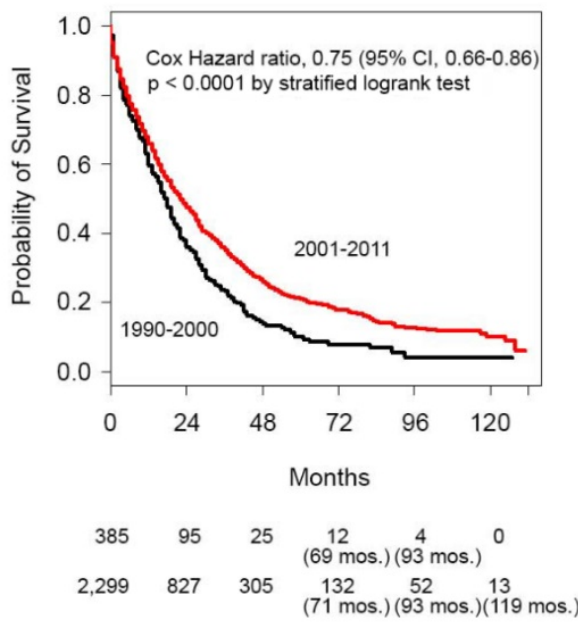

Figure 1. Survival differences between 1990-2000 and 2001-2011 in African American and Caucasian women with stage I-III and stage IV breast cancer. Kaplan-Meier survival curves for Caucasian patients and African American patients with A. stage I-III disease and B. stage IV disease diagnosed in the years 1990-2000 and 2001-2011. Differences in Cox hazard ratios were determined using the logrank test. Differences were considered significant at $P \leq 0.05$. Patients at risk are shown at $0,24,48$, 72,96 and 120 months, except in some instances where there were no deaths and alternate times are inserted in parentheses.

We stratified the data by stage, race and the six patient- and the tumor-associated variables. The results of the Cox proportional hazards regression analysis with 3-variable stratification and 4-variable stratification are shown in Tables 4 - 6. Table 4 demonstrates that Caucasian patients and African American patients had significantly lower Cox HR in the 2001-2011 time periods than in the 1990-2000 time periods in most patient- and tumor-associated variable categories. Several exceptions, including African Americans with Grade 1 disease, Caucasians and African Americans in the Separated category in the stage I-III groups and African Americans in the > 70 year, Grade 1, ER- and the Divorced and Widowed categories and Caucasians and African Americans in the Separated category in the stage IV grouping did not reach statistical significance due to low sample numbers (Table S1). The proportional hazards assumption did hold in all these cases except for Caucasians with Stage I-III disease who were $<40$ years, had grade 3 disease and who were widowed, and for African Americans with Stage IV disease who had grade 3 disease and left sided laterality (Table 4).

Improvements in survival in the latter decade were significantly different in some subgroups than in others in the stage I-III disease category, where significant differences were noted with confirmed validity of the Cox HR determinations. Elderly Caucasians had much lower improvements in survival (Cox HR 0.88 [95\% confidence intervals 0.85-0.91]) than Caucasians in the 40-69 year category (Cox HR 0.64 [95\% confidence intervals 0.62-0.66]) and elderly African Americans had worse improvements in survival (Cox HR 0.83 [95\% 
confidence intervals 0.75-0.93]) than African Americans in the < 40 year (Cox HR 0.58 [95\% confidence intervals 0.49-0.68]) or the 40-69 year (Cox HR 0.67 [95\% confidence intervals 0.62-0.72]) categories (Table 4, rows with grey shaded backgrounds). Similarly, African American widowed patients had worse improvements in survival (Cox HR 0.86 [95\% confidence intervals 0.77-0.96]) than African American women who were single (Cox HR 0.68 [95\% confidence intervals $0.60-0.76]$ ) or married (Cox HR 0.61 [95\% confidence intervals 0.55-0.67]) (Table 4, rows with grey shaded backgrounds). Caucasian patients with ER- (Cox HR 0.81 [95\% confidence intervals 0.78-0.84]) and PR- tumors (Cox HR 0.75 [95\% confidence intervals 0.73-0.78]) had much less improvement in survival in the latter decade than did Caucasians with ER+ (Cox HR 0.69 [95\% confidence intervals 0.68-0.71]) and PR+ tumors (Cox HR 0.69 [95\% confidence intervals 0.67-0.71]), respectively (Table 4, rows with grey shaded backgrounds). However, we did not find this difference in African American women with ER- and PR- tumors. In contrast, we found that there was a markedly greater improvement in the rates of survival in the latter decade in African American women with ER- (Cox HR 0.70 [95\% confidences intervals 0.65-0.76]) and PR- disease (Cox HR 0.67 [95\% confidences intervals 0.62-0.72]) than in their Caucasian counterparts (ER-, Cox HR 0.81 [95\% confidence intervals 0.78-0.84], PR-, Cox HR 0.75 [95\% confidence intervals $0.73-0.78]$ ), with the proportional hazards assumption holding in both cases (Table 4, rows with orange shaded backgrounds). This was particularly significant in the setting of less improvement in the survival of Caucasians with ERand PR- disease than of patients with corresponding hormone positive categories described above. None of the data in the stage IV group identified significant differences or trends in the improvement of the Cox HR between the two decades in any of the subgroups.

Kaplan-Meier survival curves and logrank test analysis demonstrated shrinking Cox hazard ratios comparing African Americans to Caucasians with stages I-III disease in the latter decade, for both ERdisease (Cox HR 1.55 [95\% confidence intervals 1.44-1.68] in the 1990-2000 period vs. Cox HR 1.33 [95\% confidence intervals 1.27-1.39] in the 2001-2011 period, $P<.001$ ) (Figure 2A), and PR- disease, (Cox HR 1.59 [95\% confidence intervals 1.48-1.71] in the 1990-2000 period vs. Cox HR 1.38 [95\% confidence intervals 1.33-1.43] in the 2001-2011 period, $P<.001$ ) (Figure 2B). The median survival of African Americans with stages I-III ER- tumors was 111 months (Figure 2A) and with PR- tumors was 106 months (Figure 2B) in the period 1990-2000 and was no longer reached for either group in the period 2001-2011. Caucasians with ER- and PR- tumors never reached the median survival in either decade.

Table 3. Cox Proportional hazards regression model for overall death in the years 2001-2011 compared with 1990-2000 in women with adenocarcinoma of the breast stratified by single variables of race, age grouping, stage, ER status, PR status, marital status and laterality and by race and stage.

\begin{tabular}{|c|c|c|c|c|}
\hline Variables & $\begin{array}{l}\text { Cox Hazard Ratio } \\
\text { (Confidence } \\
\text { Intervals) }\end{array}$ & $\begin{array}{l}P \\
\text { (Pearson } \\
\text { Chi } \\
\text { Square) }\end{array}$ & $\begin{array}{l}P(\text { Scaled } \\
\text { Schoenfeld } \\
\text { residuals } \\
\text { test) }\end{array}$ & $\begin{array}{l}\text { Number of } \\
\text { patients } \\
(1990-2000 / \\
2001-2011)\end{array}$ \\
\hline \multicolumn{5}{|l|}{ Caucasians } \\
\hline All stages & $0.76(0.74-0.77)$ & $<.001$ & $<.001$ & $87,453 / 266,625$ \\
\hline Stage I & $0.78(0.75-0.81)$ & $<.001$ & 0.525 & $42,854 / 131,815$ \\
\hline Stage II & $0.70(0.67-0.72)$ & $<.001$ & 0.023 & $29,922 / 92,324$ \\
\hline Stage III & $0.74(0.71-0.77)$ & $<.001$ & 0.030 & $12,171 / 31,558$ \\
\hline Stage IV & $0.72(0.68-0.76)$ & $<.001$ & 0.501 & $2,506 / 10,928$ \\
\hline \multicolumn{5}{|c|}{ African Americans } \\
\hline All stages & $0.76(0.72-0.80)$ & $<.001$ & 0.028 & $8,075 / 33,017$ \\
\hline Stage I & $0.71(0.63-0.81)$ & $<.001$ & 0.852 & $2,744 / 11,812$ \\
\hline Stage II & $0.73(0.67-0.79)$ & $<.001$ & 0.892 & $3,286 / 13,163$ \\
\hline Stage III & $0.70(0.64-0.76)$ & $<.001$ & 0.478 & $1,660 / 5,743$ \\
\hline Stage IV & $0.75(0.66-0.86)$ & $<.001$ & 0.046 & $385 / 2,299$ \\
\hline \multicolumn{5}{|c|}{ Age grouping - all patients } \\
\hline$<40$ & $0.70(0.65-0.76)$ & $<.001$ & 0.566 & $6,509 / 17,864$ \\
\hline $40-69$ & $0.72(0.70-0.74)$ & $<.001$ & $<.001$ & $61,512 / 205,977$ \\
\hline$\geq 70$ & $0.91(0.88-0.93)$ & $<.001$ & $<.001$ & $27,507 / 75,801$ \\
\hline \multicolumn{5}{|c|}{ Grade - all patients } \\
\hline 1 & $0.80(0.75-0.85)$ & $<.001$ & 0.502 & $14,676 / 58,478$ \\
\hline 2 & $0.81(0.78-0.83)$ & $<.001$ & $<.001$ & $42,043 / 126,992$ \\
\hline 3 & $0.79(0.77-0.81)$ & $<.001$ & $<.001$ & $38,809 / 114,172$ \\
\hline \multicolumn{5}{|c|}{ ER status - all patients } \\
\hline+ & $0.74(0.73-0.76)$ & $<.001$ & 0.002 & $73,138 / 235,166$ \\
\hline- & $0.86(0.83-0.89)$ & $<.001$ & $<.001$ & $22,390 / 64,476$ \\
\hline \multicolumn{5}{|c|}{ PR status - all patients } \\
\hline+ & $0.74(0.72-0.76)$ & $<.001$ & 0.015 & $64,201 / 202,903$ \\
\hline- & $0.81(0.78-0.83)$ & $<.001$ & $<.001$ & $31,327 / 96,739$ \\
\hline \multicolumn{5}{|c|}{ Marital status - all patients } \\
\hline Single & $0.81(0.76-0.85)$ & $<.001$ & 0.013 & $10,848 / 41,472$ \\
\hline Married & $0.71(0.69-0.73)$ & $<.001$ & 0.166 & $56,195 / 175,415$ \\
\hline Separated & $0.85(0.69-1.04)$ & 0.120 & 0.024 & $611 / 3,178$ \\
\hline Divorced & $0.84(0.79-0.89)$ & $<.001$ & 0.058 & $9,893 / 34,003$ \\
\hline Widowed & $0.92(0.89-0.95)$ & $<.001$ & 0.002 & $17,981 / 45,574$ \\
\hline \multicolumn{5}{|c|}{ Laterality - all patients } \\
\hline Right & $0.77(0.75-0.79)$ & $<.001$ & $<.001$ & $46,833 / 147,824$ \\
\hline Left & $0.77(0.75-0.79)$ & $<.001$ & $<.001$ & $48,695 / 151,818$ \\
\hline
\end{tabular}

These results indicate a significantly greater improvement in the Cox hazard ratios for survival of African American women with ER- and PR- breast cancer than that of Caucasians in the decade after the turn of the century. Nevertheless, survival of Caucasian women with ER- and PR- breast cancer remained greater than that of African Americans despite the documented superior improvement in survival in the latter group. We stratified the ER- and PR- data further to determine if potential changes in the distribution of tumor-associated and patientassociated co-variables could have contributed to improved survival favoring African Americans. For tumor-associated variables, we analyzed stage, grade and PR status in patients with ER- tumors and stage, 
grade and ER status in patients with PR- tumors. As in the unstratified data, some of the subcategories with sufficient elements exhibited significantly greater improvement in the Cox hazard ratio for survival in African American patients than in Caucasian patients in the decade after the century (Tables 5 and 6, rows with orange shaded backgrounds). African American women with ER- tumors had greater improvement in survival than Caucasian women with ER- tumors in the stage I category (Cox HR 0.66 [95\% confidence interval $0.55-0.81$ ] vs. Cox HR 0.89 [95\% confidence interval 0.82-0.96]), in the PR- tumor category (Cox HR 0.67 [95\% confidence interval 0.62-0.73] vs. Cox HR 0.79 [95\% confidence interval 0.76-0.82] and in the Married category (Cox HR 0.62 [95\% confidence interval 0.55-0.70] vs. Cox HR 0.77 [95\% confidence interval 0.73-0.81], respectively (Table 5). African American women with PR- tumors had greater

\section{A. ER negative tumors}

$1990-2000$

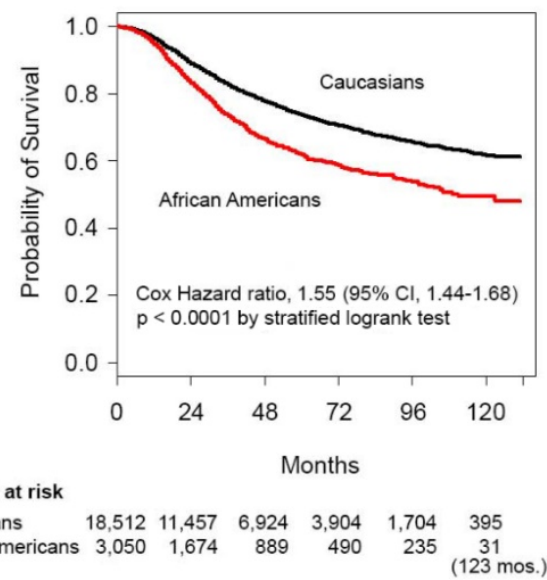

\section{B. PR negative tumors}

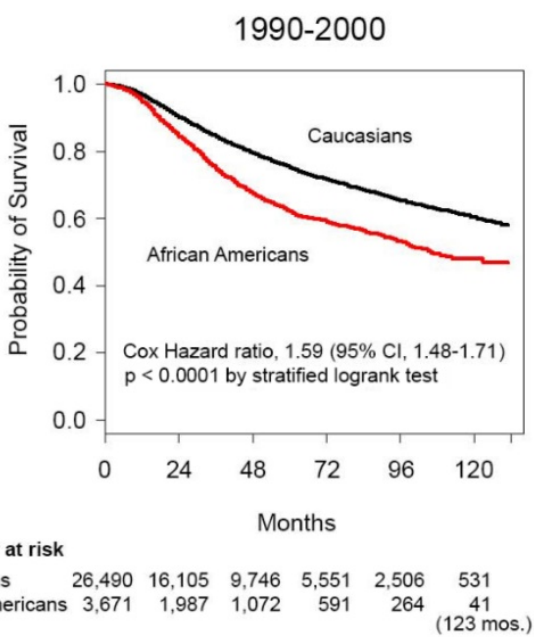

improvement in survival than their Caucasian counterparts in the $>70$ year old category (Cox HR 0.74 [95\% confidence interval $0.63-0.86]$ vs. Cox HR 0.90 [ $95 \%$ confidence interval $0.86-0.95]$, in the stage I category (Cox HR 0.61 [95\% confidence interval 0.51-0.73] vs. Cox HR 0.80 [95\% confidence interval $0.75-0.86]$, in the ER- category (Cox HR 0.67 [95\% confidence interval $0.62-0.73$ ] vs. Cox HR 0.79 [95\% confidence interval 0.76-0.82], and in the Married category (Cox HR 0.59 [95\% confidence interval $0.52-0.66$ ] vs. Cox HR 0.71 [95\% confidence interval 0.68-0.75], respectively (Table 6). African American women with PR- right sided tumors also has greater improvement in survival than their Caucasian counterparts in the latter decade (Cox HR 0.63 [95\% confidence interval 0.57-0.70] vs. Cox HR 0.77 [95\% confidence interval 0.73-0.80]. In all these noted cases, the proportional hazards assumption held.
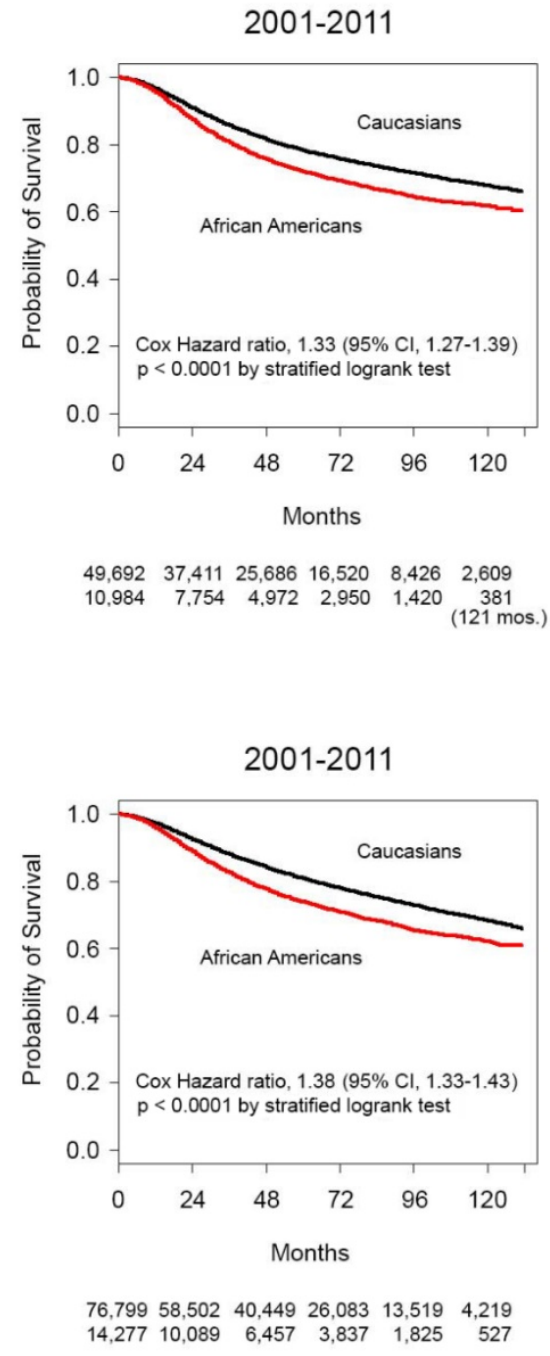

Figure 2. Survival differences and between African American and Caucasian women with stage I-III hormone negative cancer in $1990-2000$ and 2001-2011. Kaplan-Meier survival curves for patients with Stage I-III disease with A. ER negative and B. PR negative tumors diagnosed in the years 1990-2000 and 2001-2011. Differences in Cox hazard ratios were determined using the logrank test. Differences were considered significant at $P \leq 0.05$. Patients at risk are shown at $0,24,48,72,96$ and 120 months, except in some instances where there were no deaths and alternate times are inserted in parentheses. 
Table 4. Cox Proportional hazards regression model for overall death in the years 2001-2011 compared with 1990-2000 in women with adenocarcinoma of the breast stratified by three variables, stage grouping, race, and by age grouping, grade, ER status, PR status, marital status and laterality.

\begin{tabular}{|c|c|c|c|c|c|c|}
\hline & $\begin{array}{l}\text { Cox Hazard Ratio } \\
\begin{array}{l}\text { (Confidence } \\
\text { Intervals) }\end{array}\end{array}$ & $\frac{P \text { (Pearson }}{\underline{\text { Chi Square) }}}$ & $\begin{array}{l}P(\text { Scaled } \\
\text { Schoenfeld } \\
\text { residuals test) }\end{array}$ & $\begin{array}{l}\text { Cox Hazard Ratio } \\
\begin{array}{l}\text { (Confidence } \\
\text { Intervals) }\end{array}\end{array}$ & $\frac{P \text { (Pearson }}{\underline{\text { Chi Square) }}}$ & $\begin{array}{l}P(\text { Scaled } \\
\text { Schoenfeld } \\
\text { residuals test) }\end{array}$ \\
\hline & \multicolumn{3}{|c|}{ Caucasian } & \multicolumn{3}{|c|}{ African American } \\
\hline \multicolumn{7}{|c|}{ Stage I-III } \\
\hline \multicolumn{7}{|l|}{ Age groups } \\
\hline$<40$ & $0.64(0.58-0.69)$ & $<.001$ & 0.018 & $0.58(0.49-0.68)$ & $<.001$ & 0.437 \\
\hline $40-69$ & $0.64(0.62-0.66)$ & $<.001$ & 0.469 & $0.67(0.62-0.72)$ & $<.001$ & 0.712 \\
\hline$\geq 70$ & $0.88(0.85-0.91)$ & $<.001$ & 0.069 & $0.83(0.75-0.93)$ & $<.001$ & 0.667 \\
\hline \multicolumn{7}{|l|}{ Grade } \\
\hline 1 & $0.77(0.72-0.83)$ & $<.001$ & 0.728 & $0.79(0.62-1.00)$ & 0.054 & 0.608 \\
\hline 2 & $0.75(0.72-0.77)$ & $<.001$ & 0.148 & $0.74(0.66-0.82)$ & $<.001$ & 0.480 \\
\hline 3 & $0.73(0.71-0.75)$ & $<.001$ & 0.027 & $0.68(0.64-0.73)$ & $<.001$ & 0.481 \\
\hline \multicolumn{7}{|l|}{ ER status } \\
\hline+ & $0.69(0.68-0.71)$ & $<.001$ & 0.584 & $0.71(0.65-0.76)$ & $<.001$ & 0.283 \\
\hline- & $0.81(0.78-0.84)$ & $<.001$ & 0.057 & $0.70(0.65-0.76)$ & $<.001$ & 0.162 \\
\hline \multicolumn{7}{|l|}{ PR Status } \\
\hline+ & $0.69(0.67-0.71)$ & $<.001$ & 0.609 & $0.73(0.67-0.79)$ & $<.001$ & 0.075 \\
\hline- & $0.75(0.73-0.78)$ & $<.001$ & 0.399 & $0.67(0.62-0.72)$ & $<.001$ & 0.106 \\
\hline \multicolumn{7}{|l|}{$\begin{array}{l}\text { Marital } \\
\text { Status }\end{array}$} \\
\hline Single & $0.70(0.65-0.75)$ & $<.001$ & 0.966 & $0.68(0.60-0.76)$ & $<.001$ & 0.688 \\
\hline Married & $0.67(0.65-0.69)$ & $<.001$ & 0.285 & $0.61(0.55-0.67)$ & $<.001$ & 0.534 \\
\hline Separated & $0.81(0.62-1.07)$ & 0.134 & 0.535 & $0.72(0.50-1.04)$ & 0.081 & 0.075 \\
\hline Divorced & $0.78(0.73-0.84)$ & $<.001$ & 0.807 & $0.75(0.64-0.87)$ & $<.001$ & 0.798 \\
\hline Widowed & $0.90(0.86-0.93)$ & $<.001$ & 0.020 & $0.86(0.77-0.96)$ & 0.009 & 0.560 \\
\hline \multicolumn{7}{|l|}{ Laterality } \\
\hline Right & $0.73(0.71-0.75)$ & $<.001$ & 0.261 & $0.67(0.61-0.72)$ & $<.001$ & 0.526 \\
\hline Left & $0.70(0.68-0.73)$ & $<.001$ & 0.319 & $0.72(0.67-0.78)$ & $<.001$ & 0.956 \\
\hline \multicolumn{7}{|c|}{ Stage IV } \\
\hline \multicolumn{7}{|l|}{ Age groups } \\
\hline$<40$ & $0.73(0.56-0.93)$ & 0.013 & 0.742 & $0.63(0.41-0.97)$ & 0.036 & 0.731 \\
\hline $40-69$ & $0.71(0.66-0.77)$ & $<.001$ & 0.182 & $0.74(0.63-0.87)$ & $<.001$ & 0.061 \\
\hline$\geq 70$ & $0.77(0.70-0.84)$ & $<.001$ & 0.453 & $0.94(0.72-1.23)$ & 0.666 & 0.428 \\
\hline \multicolumn{7}{|l|}{ Grade } \\
\hline 1 & $0.77(0.57-1.03)$ & 0.080 & 0.945 & $0.55(0.28-1.10)$ & 0.090 & 0.287 \\
\hline 2 & $0.67(0.61-0.74)$ & $<.001$ & 0.448 & $0.71(0.55-0.91)$ & 0.008 & 0.382 \\
\hline 3 & $0.77(0.72-0.83)$ & $<.001$ & 0.550 & $0.81(0.69-0.95)$ & 0.008 & 0.035 \\
\hline \multicolumn{7}{|l|}{ ER status } \\
\hline+ & $0.71(0.66-0.76)$ & $<.001$ & 0.231 & $0.68(0.57-0.81)$ & $<.001$ & 0.679 \\
\hline- & $0.74(0.67-0.81)$ & $<.001$ & 0.687 & $0.85(0.69-1.04)$ & 0.109 & 0.080 \\
\hline \multicolumn{7}{|l|}{ PR Status } \\
\hline+ & $0.71(0.66-0.77)$ & $<.001$ & 0.138 & $0.70(0.57-0.86)$ & $<.001$ & 0.928 \\
\hline- & $0.69(0.64-0.75)$ & $<.001$ & 0.535 & $0.81(0.68-0.96)$ & 0.014 & 0.024 \\
\hline \multicolumn{7}{|l|}{$\begin{array}{l}\text { Marital } \\
\text { Status }\end{array}$} \\
\hline Single & $0.73(0.62-0.85)$ & $<.001$ & 0.726 & $0.78(0.62-0.99)$ & 0.042 & 0.367 \\
\hline Married & $0.71(0.65-0.77)$ & $<.001$ & 0.092 & $0.74(0.58-0.94)$ & 0.016 & 0.200 \\
\hline Separated & $0.99(0.45-2.14)$ & 0.972 & 0.777 & $0.76(0.32-1.79)$ & 0.530 & 0.223 \\
\hline Divorced & $0.71(0.60-0.84)$ & $<.001$ & 0.582 & $0.77(0.55-1.07)$ & 0.118 & 0.121 \\
\hline Widowed & $0.78(0.70-0.87)$ & $<.001$ & 0.501 & $0.76(0.57-1.01)$ & 0.060 & 0.597 \\
\hline \multicolumn{7}{|l|}{ Laterality } \\
\hline Right & $0.70(0.65-0.76)$ & $<.001$ & 0.650 & $0.81(0.67-0.98)$ & 0.026 & 0.851 \\
\hline Left & $0.73(0.67-0.79)$ & $<.001$ & 0.174 & $0.70(0.58-0.84)$ & $<.001$ & 0.007 \\
\hline
\end{tabular}

Analysis of tumor-associated variables showed that there was a small decrease in the distribution of Caucasian patients with stage III disease in years 2001-2011 but no corresponding change in the distribution of African American patients with stage III disease in the ER- patient group (Table 5). Both Caucasians and African Americans had more grade 3 and PR- tumors that were ER- in the latter decade, suggesting a small increase in the aggressiveness of ER- tumors. In the PR- patient group, the stage differences were similar to the ER-group, indicating a small decrease stage III Caucasian patients in years 2001-2011 but without change in stage III African
American patients (Table 6). There were slightly more Caucasian patients with grade 3 tumors but the increase in African Americans did not reach statistical significance (Table 6). African Americans with PRtumors had a small decrease in the distribution of ERtumors in the latter decade but the change in Caucasians was not significant. These data support the position that changes in these tumor-associated variables did not contribute to the significantly greater improvement in the Cox hazard ratios for survival of African American patients with ER- and PR- disease in 2001-2011 compared to the prior decade. 
Table 5. Cox Proportional hazards regression model for overall death in the years 2001-2011 compared with 1990-2000 in women with ER- adenocarcinoma of the breast stage I-III stratified by race, and by age grouping, stages I, II or III, grade, PR status, marital status and laterality.

\begin{tabular}{|c|c|c|c|c|c|c|c|c|c|c|}
\hline & $\begin{array}{l}\text { Cox Hazard } \\
\text { Ratio } \\
\text { (Confidence } \\
\text { Intervals) }\end{array}$ & $\begin{array}{l}\frac{P}{\text { (Pearson }} \\
\underline{\text { Chi }} \\
\underline{\text { Square) }}\end{array}$ & $\begin{array}{c}P(\text { Scaled } \\
\text { Schoenfeld } \\
\text { residuals } \\
\text { test })\end{array}$ & $\begin{array}{c}\text { Number of } \\
\text { patients } \\
1990-2000\end{array}$ & $\begin{array}{c}\text { Number of } \\
\text { patients } \\
2001-2011\end{array}$ & $\begin{array}{l}\text { Cox Hazard } \\
\text { Ratio } \\
\text { (Confidence } \\
\text { Intervals) }\end{array}$ & $\begin{array}{l}\frac{P}{\text { (Pearson }} \\
\text { Chi } \\
\text { Square) }\end{array}$ & $\begin{array}{c}P(\text { Scaled } \\
\text { Schoenfeld } \\
\text { residuals } \\
\text { test) }\end{array}$ & $\begin{array}{c}\text { Number of } \\
\text { patients } \\
1990-2000\end{array}$ & $\begin{array}{c}\text { Number of } \\
\text { patients } \\
2001-2011\end{array}$ \\
\hline & \multicolumn{5}{|c|}{ Caucasian } & \multicolumn{5}{|c|}{ African American } \\
\hline $\begin{array}{l}\text { Total } \\
\text { number }\end{array}$ & & & & $18,512(\%)$ & $49,692(\%)$ & & & & $3,050(\%)$ & $10,984(\%)$ \\
\hline \multicolumn{11}{|l|}{$\begin{array}{l}\text { Age } \\
\text { groups }\end{array}$} \\
\hline$<40$ & $0.73(0.64-0.83)$ & $<.001$ & 0.846 & $2,093(11.3)$ & $4,776(9.6)$ & $0.65(0.52-0.79)$ & $<.001$ & 0.493 & $471(15.4)$ & $1,207(11.0)$ \\
\hline $40-69$ & $0.78(0.74-0.82)$ & $<.001$ & 0.080 & $12,644(68.3)$ & $35,128(70.7)$ & $0.69(0.63-0.76)$ & $<.001$ & 0.048 & $2,186(71.7)$ & $8,266(75.3)$ \\
\hline$\geq 70$ & $0.91(0.85-0.97)$ & .004 & 0.195 & $3,775(20.4)$ & $9,788(19.7)$ & $0.76(0.63-0.91)$ & 0.003 & 0.938 & $393(12.9)$ & $1,511(13.7)$ \\
\hline \multicolumn{6}{|c|}{$P<.001$ (Chi square) } & \multicolumn{5}{|c|}{$P<.001$ (Chi square) } \\
\hline \multicolumn{11}{|l|}{ Stage } \\
\hline 1 & $0.89(0.82-0.96)$ & 0.005 & 0.577 & $7,308(39.5)$ & $19,102(38.4)$ & $0.66(0.55-0.81)$ & $<.001$ & 0.868 & $907(29.7)$ & $3,286(29.9)$ \\
\hline II & $0.78(0.73-0.82)$ & $<.001$ & 0.317 & $7,654(41.3)$ & $21,667(43.6)$ & $0.70(0.62-0.79)$ & $<.001$ & 0.297 & $1,443(47.3)$ & $5,257(47.9)$ \\
\hline III & $0.81(0.76-0.86)$ & $<.001$ & 0.005 & $3,550(19.2)$ & $8,923(18.0)$ & $0.68(0.60-0.76)$ & $<.001$ & 0.065 & $700(23.0)$ & $2,441(22.2)$ \\
\hline & \multicolumn{5}{|c|}{$P<.001$ (Chi square) } & \multicolumn{5}{|c|}{$P=0.690^{*}$ (Chi square) } \\
\hline \multicolumn{11}{|l|}{ Grade } \\
\hline 1 & $1.13(0.87-1.47)$ & $0.3496^{*}$ & 0.469 & $790(4.3)$ & $1,270(2,6)$ & $1.17(0.55-2.49)$ & $0.678^{\star}$ & 0.092 & $70(2.3)$ & $164(1.5)$ \\
\hline 2 & $0.86(0.79-0.94)$ & $<.001$ & 0.105 & $4,530(24.5)$ & $9,614(19.3)$ & $0.68(0.56-0.83)$ & $<.001$ & 0.851 & $572(18.8)$ & $1,756(16.0)$ \\
\hline 3 & $0.76(0.73-0.80)$ & $<.001$ & 0.451 & $13,192(71.2)$ & $38,808(78.1)$ & $0.69(0.63-0.75)$ & $<.001$ & $0.110)$ & $2,408(78.9)$ & $9,064(82.5)$ \\
\hline \multicolumn{6}{|c|}{$P<.001$ (Chi square) } & \multicolumn{5}{|c|}{$P<.001$ (Chi square) } \\
\hline \multicolumn{11}{|l|}{ PR Status } \\
\hline+ & $0.83(0.73-0.93)$ & 0.002 & 0.935 & $2,600(14.0)$ & $3,178(6.4)$ & $0.98(0.75-1.29)$ & $0.900^{*}$ & 0.977 & $325(10.7)$ & $623(5.7)$ \\
\hline- & $0.79(0.76-0.82)$ & $<.001$ & 0.079 & $15,912(86.0)$ & $46,514(93.6)$ & $0.67(0.62-0.73)$ & $<.001$ & 0.169 & $2,725(89.3)$ & $10,361(94.3)$ \\
\hline \multicolumn{6}{|c|}{$P<.001$ (Chi square) } & \multicolumn{5}{|c|}{$P<.001$ (Chi square) } \\
\hline \multicolumn{11}{|l|}{$\begin{array}{l}\text { Marital } \\
\text { Status }\end{array}$} \\
\hline Single & $0.75(0.67-0.84)$ & $<.001$ & 0.087 & $1,902(10.3)$ & $5,793(11.7)$ & $0.71(0.61-0.83)$ & $<.001$ & 0.182 & $721(23.6)$ & $3,333(30.3)$ \\
\hline Married & $0.77(0.73-0.81)$ & $<.001$ & 0.280 & $11,901(64.3)$ & $31,409(63.2)$ & $0.62(0.55-0.70)$ & $<.001$ & 0.759 & $1,333(43.7)$ & $4,376(39.8)$ \\
\hline Separated & $0.98(0.65-1.47)$ & $0.909^{\star}$ & 0.322 & $126(0.7)$ & $530(1.1)$ & $0.84(0.49-1.44)$ & $0.535^{\star}$ & 0.109 & $72(2.4)$ & $261(2.4)$ \\
\hline Divorced & $0.89(0.79-0.99)$ & 0.040 & 0.040 & $1,994(10.8)$ & $5,624(11.3)$ & $0.69(0.57-0.85)$ & $<.001$ & 0.160 & $503(16.5)$ & $1,695(15.4)$ \\
\hline Widowed & $0.93(0.86-1.01)$ & $0.078^{*}$ & 0.178 & $2,589(14.0)$ & $6,336(12.7)$ & $0.87(0.72-1.05)$ & $0.134^{*}$ & 0.189 & $421(13.8)$ & $1,319(12.0)$ \\
\hline \multicolumn{6}{|c|}{$P<.001$ (Chi square) } & \multicolumn{5}{|c|}{$P<.001$ (Chi square) } \\
\hline \multicolumn{11}{|l|}{ Laterality } \\
\hline Right & $0.81(0.77-0.85)$ & $<.001$ & 0.719 & $8,976(48.5)$ & $24,073(48.4)$ & $0.70(0.63-0.79)$ & $<.001$ & 0.132 & $1,499(49.1)$ & $5,304(48.3)$ \\
\hline Left & $0.81(0.77-0.86)$ & $<.001$ & 0.024 & $9,536(51.5)$ & $25,619(51.6)$ & $0.70(0.63-0.78)$ & $<.001$ & 0.613 & $1,551(50.9)$ & $5,680(51.7)$ \\
\hline \multicolumn{6}{|c|}{$P=0.920^{*}$ (Chi square) } & & & & \multicolumn{2}{|c|}{$P=0.401^{*}($ Chi square $)$} \\
\hline
\end{tabular}

*Not significant

Analysis of patient-associated variables revealed that in both the ER- and the PR- stratified groups, there was a decrease in the under 40 year-old patient group but an increase in the single patient group in both Caucasians and African Americans (Tables 5 and 6). These data do not support contributions by changes in adverse patient prognostic characteristics to the disparate changes in survival. Combined with the lack of tumor-associated contributions, the data raise the possibility that perhaps, treatmentassociated factors may be contributing to the differences in the changes in survival in patients with ER- and PR- tumors, countering conventional wisdom.

\section{Discussion}

Our data demonstrate that, while most groups of patients with breast cancer had improved survival in the first decade of the century, African American women with ER- and PR- stage I-III disease had significantly greater improvement than their Caucasian counterparts. This stood in contrast to some subgroups who fared less well and had less improvement in survival than other patients in their respective stratification categories, including ER- and PR- Caucasian patients, elderly Caucasian and African American patients and widowed African
American patients with stage I-III disease. These results support the fact that analyses by population averaging patients with a disease characterized by many variables will mask the existence of significant differences in certain subsets. In fact, our unstratified data showed overlapping confidence intervals for survival improvement spanning the two decades in African Americans and Caucasians for both groupings of stage I-III disease and stage IV disease. These results were in line with prior observations $(5$, 34). In one example, a study of the SEER Medicare databases that demonstrated no change in the absolute difference in survival between matched African Americans and Caucasians over 65 between 1991 and 2005 concluded that differences in survival appeared primarily related to presentation characteristics at diagnosis rather than treatment differences (5). Indeed, when we stratified the data by one variable or multiple variables, differences in survival became evident. Stratification is necessary in this type of analysis due to diverging distributions of variables with time and covariance among associated variables (21). The SEER database did not begin incorporating measurements for Her2/neu, another important prognostic variable, until 2010, so it could not be part of our analysis and presented a limitation on this investigation. 
Table 6. Cox Proportional hazards regression model for overall death in the years 2001-2011 compared with 1990-2000 in women with PR- adenocarcinoma of the breast stage I-III stratified by race, and by age grouping, stages I, II or III, grade, ER status, marital status and laterality.

\begin{tabular}{|c|c|c|c|c|c|c|c|c|c|c|}
\hline & $\begin{array}{l}\text { Cox Hazard } \\
\text { Ratio } \\
\text { (Confidence } \\
\text { Intervals) }\end{array}$ & $\begin{array}{l}\frac{P}{\text { (Pearson }} \\
\frac{\text { Chi }}{\text { Square) }}\end{array}$ & $\begin{array}{l}P(\text { Scaled } \\
\text { Schoenfeld } \\
\text { residuals } \\
\text { test) }\end{array}$ & $\begin{array}{c}\text { Number of } \\
\text { patients } \\
1990-2000\end{array}$ & $\begin{array}{l}\text { Number of } \\
\text { patients } \\
2001-2011\end{array}$ & $\begin{array}{l}\text { Cox Hazard } \\
\text { Ratio } \\
\begin{array}{l}\text { (Confidence } \\
\text { Intervals) }\end{array}\end{array}$ & $\begin{array}{l}\frac{P}{\text { Pearson }} \\
\underline{\text { Chi }} \\
\underline{\text { Square })}\end{array}$ & $\begin{array}{l}P(\text { Scaled } \\
\text { Schoenfeld } \\
\text { residuals } \\
\text { test })\end{array}$ & $\begin{array}{c}\text { Number of } \\
\text { patients } \\
1990-2000\end{array}$ & $\begin{array}{l}\text { Number of } \\
\text { patients } \\
2001-2011\end{array}$ \\
\hline & \multicolumn{5}{|c|}{ Caucasian } & \multicolumn{5}{|c|}{ African American } \\
\hline number & & & & $26,490(\%)$ & $76,799(\%)$ & & & & $3,671(\%)$ & $14,277(\%)$ \\
\hline \multicolumn{11}{|l|}{$\begin{array}{l}\text { Age } \\
\text { groups }\end{array}$} \\
\hline$<40$ & $0.69(0.61-0.78)$ & $<.001$ & 0.790 & $2,295(8.7)$ & $5,824(7.6)$ & $0.59(0.48-0.72)$ & $<.001$ & 0.712 & $503(13.7)$ & $1,443(10.1)$ \\
\hline $40-69$ & $0.70(0.67-0.73)$ & $<.001$ & 0.634 & $17,068(64.4)$ & $52,725(68.7)$ & $0.66(0.60-0.72)$ & $<.001$ & 0.039 & $2,562(69.8)$ & $10,577(74.1)$ \\
\hline$\geq 70$ & $0.90(0.86-0.95)$ & $<.001$ & 0.343 & $7,127(26.9)$ & $18,250(23.8)$ & $0.74(0.63-0.86)$ & $<.001$ & 0.642 & $606(16.5)$ & $2,257(15.8)$ \\
\hline \multicolumn{6}{|c|}{$P<.001$ (Chi square) } & \multirow{2}{*}{\multicolumn{5}{|c|}{$P<.001$ (Chi square) }} \\
\hline \multicolumn{7}{|l|}{ Stage } & & & & \\
\hline 1 & $0.80(0.75-0.86)$ & $<.001$ & 0.968 & $11,534(43.5)$ & $32,877(42.8)$ & $0.61(0.51-0.73)$ & $<.001$ & 0.406 & $1,157(31.5)$ & $4,597(32.2)$ \\
\hline II & $0.73(0.69-0.77)$ & $<.001$ & 0.218 & $10,277(38.8)$ & $31,324(40.8)$ & $0.67(0.59-0.75)$ & $<.001$ & 0.495 & $1,664(45.3)$ & $6,580(46.1)$ \\
\hline III & $0.76(0.72-0.80)$ & $<.001$ & 0.114 & $4,679(17.7)$ & $12,598(16.4)$ & $0.68(0.61-0.76)$ & $<.001$ & 0.057 & $850(23.2)$ & $3,100(21.7)$ \\
\hline \multicolumn{6}{|c|}{$P<.001$ (Chi square) } & \multicolumn{5}{|c|}{$P=0.170^{*}$ (Chi square) } \\
\hline \multicolumn{11}{|l|}{ Grade } \\
\hline 1 & $0.88(0.75-1.03)$ & $0.117^{\star}$ & 0.911 & $2,247(8.5)$ & $6,611(8.6)$ & $0.72(0.46-1.12)$ & $0.146^{*}$ & 0.875 & $171(4.7)$ & $591(4.1)$ \\
\hline 2 & $0.77(0.73-0.82)$ & $<.001$ & 0.797 & $8,480(32,0)$ & $21,790(28.4)$ & $0.64(0.55-0.76)$ & $<.001$ & 0.684 & $861(23.5)$ & $3,149(22.1)$ \\
\hline 3 & $0.73(0.70-0.76)$ & $<.001$ & 0.519 & $15,763(59.5)$ & $48,398(63.0)$ & $0.66(0.61-0.72)$ & $<.001$ & 0.081 & $2,639(71.9)$ & $10,537(73.8)$ \\
\hline \multicolumn{6}{|c|}{$P<.001$ (Chi square) } & \multicolumn{5}{|c|}{$P=\mathbf{0 . 0 5 3}^{*}$ (Chi square) } \\
\hline \multicolumn{11}{|l|}{ ER Status } \\
\hline+ & $0.69(0.66-0.73)$ & $<.001$ & 0.070 & $10,578(39.9)$ & $30,285(39.4)$ & $0.66(0.56-0.77)$ & $<.001$ & 0.570 & $946(25.8)$ & $3,916(27.4)$ \\
\hline- & $0.79(0.76-0.82)$ & $<.001$ & 0.079 & $15,912(60.1)$ & $46,514(60.6)$ & $0.67(0.62-0.73)$ & $<.001$ & 0.169 & $2,725(74.2)$ & $10,361(72.6)$ \\
\hline \multicolumn{6}{|c|}{$P=0.153^{*}$ (Chi square) } & \multicolumn{5}{|c|}{$P=0.044$ (Chi square) } \\
\hline \multicolumn{11}{|l|}{$\begin{array}{l}\text { Marital } \\
\text { Status }\end{array}$} \\
\hline Single & $0.75(0.68-0.83)$ & $<.001$ & 0.039 & $2,660(10.0)$ & $8,881(11.6)$ & $0.66(0.57-0.77)$ & $<.001$ & 0.145 & $870(23.7)$ & $4,220(29.6)$ \\
\hline Married & $0.71(0.68-0.75)$ & $<.001$ & 0.908 & $16,208(61.2)$ & $47,515(61.9)$ & $0.59(0.52-0.66)$ & $<.001$ & 0.925 & $1,549(42.2)$ & $5,572(39.0)$ \\
\hline Separated & $0.87(0.60-1.26)$ & $0.462^{*}$ & 0.355 & $155(0.6)$ & $781(1.0)$ & $0.81(0.48-1.37)$ & $0.426^{*}$ & 0.513 & $82(2.2)$ & $326(2.3)$ \\
\hline Divorced & $0.77(0.70-0.85)$ & $<.001$ & 0.326 & $2,780(10.5)$ & $8,547(11.1)$ & $0.70(0.58-0.85)$ & $<.001$ & 0.195 & $581(15.8)$ & $2,213(15.5)$ \\
\hline Widowed & $0.93(0.87-0.98)$ & 0.015 & 0.287 & $4,687(17.7)$ & $11,075(14.4)$ & $0.81(0.69-0.95)$ & 0.009 & 0.949 & $589(16.0)$ & $1,946(13.6)$ \\
\hline \multicolumn{6}{|c|}{$P<.001$ (Chi square) } & \multirow{2}{*}{\multicolumn{5}{|c|}{$P<.001$ (Chi square) }} \\
\hline \multicolumn{6}{|l|}{ Laterality } & & & & & \\
\hline Right & $0.77(0.73-0.80)$ & $<.001$ & 0.832 & $12,869(48.6)$ & $37,483(48.8)$ & $0.63(0.57-0.70)$ & $<.001$ & 0.121 & $1,803(49.1)$ & $6.926(48.5)$ \\
\hline \multirow{2}{*}{\multicolumn{6}{|c|}{\begin{tabular}{r|r}
$13621(51.4)$ & $39,316(51.2)$ \\
$P=0.526^{*}($ Chi square $)$
\end{tabular}}} & $0.70(0.63-0.77)$ & $<.001$ & 0.437 & $1,868(50.9)$ & $7,351(51.5)$ \\
\hline & & & & & & \multicolumn{5}{|c|}{$P=\mathbf{0 . 5 1 4}^{*}($ Chi square $)$} \\
\hline
\end{tabular}

*Not significant

This study is the first to report greater improvement in survival in a subgroup of African American women with breast cancer than in their Caucasian counterparts. In contrast, other studies of different time periods, subgroup analyses and databases documented persistence of a stable $(35,42)$ or in some cases, a temporally progressive disparity in survival between African American and Caucasian women $(28-31,43)$. As we noted earlier, several studies that reported persistence of disparities in the overall populations presented data that, on closer inspection, suggested comparatively improved survival in subsets of African American women (1, 36, 37). While these studies did not note and did not analyze these observations, they provided the first hints for a greater increase in survival for a subset of African Americans.

With respect to the causes for the trends we observed, our analysis provides some potential insight. Further stratification of the ER- and PR- Caucasian and African American patients by the tumorassociated and patient-associated variables that we analyzed for our whole dataset did not support a role for these co-variables in the greater improvement in the survival of the hormone receptor negative African American population that we observed. On this basis, we hypothesize that perhaps treatment-associated variables may have played a role.

An interesting observation was a statistically significantly greater improvement in the hazard ratio for survival in the second decade for PR- African American compared with PR- Caucasian patients with right sided breast cancer (Table 6). A similar result was not observed with patients with right sided ER- tumors (Table 5). This was likely due to a greater difference between the fraction of PR- African American and Caucasian patients whose tumors were also ER- (Table 6) than between the two groups with ER- tumors that were also PR- (Table 5). This increase in the improved hazard ratio in the higher ER-/PRpopulation in Table 6 paralleled the greater improvement in survival we documented with ERand PR- tumors separately in African Americans. The fact that the difference was only observed in right sided tumors may be related to the differential effects of radiation therapy on right vs. left sided tumors on the long term adverse cardiovascular effects that result from the non-equal incidental radiation of the 
heart in left sided breast cancer (44-46). This likely negated the ER- and PR- tumor distribution effects on left sided tumors.

The causes of lower rates of improvement in the survival of elderly and widowed patients with localized disease and of Caucasians with ER- and PRdisease compared with those observed in younger patients and patients with ER+ and PR+ disease, respectively, may be multivariate. Standard guideline therapy, including surgery, are not administered to elderly patients at the same rate as to younger women (47-50). Co-morbidities in older women often result in faster deterioration following chemotherapy than in younger women and are significant factors in therapeutic decisions and survival (51). Perhaps the relative lack of progress in effective novel therapies for hormone receptor negative breast cancer left the ER- and PR- groups lagging behind the category of patients with hormone sensitive disease.

A possible reason for the greater improvement in the survival of African American patients with ERand PR-disease is a general improvement in the rate of appropriate treatment of minority patients with localized breast cancer (52). A greater national focus on clinical trial participation by African Americans through programmatic efforts may have also raised the general awareness of appropriate treatment and cancer control $(53,54)$. Thus, we may not be witnessing an improved survival in appropriately treated patients but in fact, we may be seeing the effects of an improvement in the fraction of the African American population receiving appropriate treatment. The lower improvement in the Caucasian population with the same disease category may indicate that in fact, a limit of effectiveness of treatment for hormone receptor negative disease has been reached with current therapies and that African American patients are catching up to these limits. It is entirely possible that the bridging of disparities in survival in this subpopulation may reach a limit with current therapy due to reported biological differences responsible for more aggressive behavior of hormone negative cancer in African American women (55-59). Nevertheless, our study is the first to demonstrate that African Americans with ER- and PR- disease benefitted significantly more than Caucasians with ER- and PR- disease in the $21^{\text {st }}$ century. Clearly more effort is needed to eliminate social disparities (27), to understand disparities based on tumor biology and to target these molecular differences.

\section{Supplementary Material}

Supplementary table S1.

http://www.jcancer.org/v11p2808s1.pdf

\section{Acknowledgements}

Support: National Cancer Institute U10CA12 8506, National Institutes of Health - partial salary support for R.W.; National Institutes of Health R01GM118574 - partial salary support for R.W., B.S. and N.A.; National Science Foundation CNS-1624503 and CNS-1747728 - partial support for BS and N.A.; Rutgers Newark Chancellor Seed Program - provides funds for computational resources to N.A.

The content is solely the responsibility of the authors and does not necessarily represent the official views of the agencies funding the research.

\section{Ethical standards}

Experiments comply with the current laws of the country in which they were performed.

\section{Competing Interests}

The authors have declared that no competing interest exists.

\section{References}

1. Smigal C, Jemal A, Ward E, et al. Trends in breast cancer by race and ethnicity: update 2006. CA: a Cancer Journal for Clinicians 2006; 56:168-83.

2. Clegg LX, Li FP, Hankey BF, et al. Cancer survival among US whites and minorities: a SEER (Surveillance, Epidemiology, and End Results) Program population-based study. Archives of Internal Medicine 2002; 162:1985-93.

3. Bach PB, Schrag D, Brawley OW, et al. Survival of blacks and whites after a cancer diagnosis. JAMA 2002; 287:2106-13.

4. Wheeler SB, Reeder-Hayes KE, Carey LA. Disparities in breast cancer treatment and outcomes: biological, social, and health system determinants and opportunities for research. Oncologist 2013; 18:986-93.

5. Silber JH, Rosenbaum PR, Clark AS, et al. Characteristics associated with differences in survival among black and white women with breast cancer. JAMA 2013; 310:389-97.

6. DeSantis C, Ma J, Bryan L, Jemal A. Breast cancer statistics, 2013. CA: a Cancer Journal for Clinicians. 2014; 64:52-62.

7. Adami HO, Malker B, Holmberg L, et al. The relation between survival and age at diagnosis in breast cancer. New Eng J Med 1986; 315:559-63.

8. Fisher B, Redmond C, Fisher ER, et al. Relative worth of estrogen and progesterone receptor and pathologic characteristics of differentiation as indicators of prognosis in node-negative breast cancer patients: findings from National Surgical Adjuvant Breast and Bowel Protocol B-06. J Clin Oncol 1988; 6:1076-87.

9. Alexieva-Figusch J, van Putten WL, Blankenstein MA, et al.. The prognostic value and relationships of patient characteristics, estrogen and progestin receptors, and site of relapse in primary breast cancer. Cancer $1988 ; 61: 758-68$.

10. Henson DE, Ries L, Freedman L, et al. Relationship among outcome, stage of disease, and histologic grade for 22,616 cases of breast cancer. Cancer 1991; 68:2142-9.

11. Molino A, Turazza M, Bonetti A, et al. Estrogen and progesterone receptors in breast cancer: correlation with clinical and pathological features and with prognosis. Oncology 1992; 49:82-8.

12. de la Rochefordiere A, Asselain B, Campana F, et al. Age as prognostic factor in premenopausal breast carcinoma. Lancet 1993; 341:1039-43.

13. Albain KS, Allred DC, Clark GM. Breast cancer outcome and predictors of outcome: are there age differentials? J Natl Cancer Inst Mongr 1994; 35-42. 
14. Nixon AJ, Neuberg D, Hayes DF, et al. Relationship of patient age to pathologic features of the tumor and prognosis for patients with stage I or II breast cancer. J Clin Oncol 1994; 12:888-94.

15. Chung M, Chang HR, Bland KI, et al. Younger women with breast carcinoma have a poorer prognosis than older women. Cancer 1996; 77:97-103.

16. Dubsky PC, Gnant MF, Taucher S, et al. Young age as an independent adverse prognostic factor in premenopausal patients with breast cancer. Clin Breast Cancer 2002; 3:65-72.

17. Han W, Kim SW, Park IA, et al. Young age: an independent risk factor for disease-free survival in women with operable breast cancer. BMC Cancer 2004; 4:82.

18. Osborne C, Ostir GV, Du X, et al. The influence of marital status on the stage at diagnosis, treatment, and survival of older women with breast cancer. Breast Cancer Research \& Treatment 2005; 93:41-7.

19. Liu $\mathrm{P}, \mathrm{Li} \mathrm{X}$, Mittendorf EA, Li J, et al. Comparison of clinicopathologic features and survival in young American women aged 18-39 years in different ethnic groups with breast cancer. British J Cancer 2013; 109:1302-9.

20. Schwartz AM, Henson DE, Chen D, et al. Histologic grade remains a prognostic factor for breast cancer regardless of the number of positive lymph nodes and tumor size: a study of 161708 cases of breast cancer from the SEER Program. Archives of Pathology \& Laboratory Medicine 2014; 138:1048-52.

21. Wieder R, Shafiq B, Adam N. African American race is an independent risk factor in survival form initially diagnosed localized breast cancer. J Cancer 2016; 7:1587-98.

22. Woods SE, Luking R, Atkins B, et al. Association of race and breast cancer stage. J National Medical Association 2006; 98:683-6.

23. Iqbal J, Ginsburg O, Rochon PA, et al. Differences in breast cancer stage at diagnosis and cancer-specific survival by race and ethnicity in the United States. JAMA 2015; 313:165-73.

24. Henson DE, Chu KC, Levine PH. Histologic grade, stage, and survival in breast carcinoma: comparison of African American and Caucasian women. Cancer 2003; 98:908-17.

25. Setiawan VW, Monroe KR, Wilkens LR, et al. Breast cancer risk factors defined by estrogen and progesterone receptor status: the multiethnic cohort study. American Journal of Epidemiology 2009; 169:1251-9.

26. Stark A, Kleer CG, Martin I, et al. African ancestry and higher prevalence of triple-negative breast cancer: findings from an international study. Cancer 2010; 116:4926-32.

27. Daly B, Olopade OI. A perfect storm: How tumor biology, genomics, and health care delivery patterns collide to create a racial survival disparity in breast cancer and proposed interventions for change. CA: a Cancer Journal for Clinicians 2015; 65:221-38.

28. Chevarley F, White E: Recent trends in breast cancer mortality among white and black US women. American Journal of Public Health 1997; 87:775-81.

29. Jatoi I, Becher H, Leake CR. Widening disparity in survival between white and African-American patients with breast carcinoma treated in the U. S. Department of Defense Healthcare system. Cancer 2003; 98:894-9.

30. Sarker M, Jatoi I, Becher H. Racial differences in breast cancer survival in women under age 60. Breast Cancer Research \& Treatment 2007; 106:135-41

31. Jemal A, Thun MJ, Ries LA, et al. Annual report to the nation on the status of cancer, 1975-2005, featuring trends in lung cancer, tobacco use, and tobacco control. J National Cancer Institute 2008; 100:1672-94

32. Chatterjee NA, He Y, Keating NL. Racial differences in breast cancer stage at diagnosis in the mammography era. American J Public Health 2013; 103:170-6.

33. Zeng C, Wen W, Morgans AK, et al. Disparities by Race, Age, and Sex in the Improvement of Survival for Major Cancers: Results from the National Cancer Institute Surveillance, Epidemiology, and End Results (SEER) Program in the United States, 1990 to 2010. JAMA Oncology 2015; 1:88-96.

34. Kohler BA, Sherman RL, Howlader N, et al. Annual Report to the Nation on the Status of Cancer, 1975-2011, Featuring Incidence of Breast Cancer Subtypes by Race/Ethnicity, Poverty, and State. J National Cancer Institute 2015; 107:djv048.

35. Howlader N, Noone AM, Krapcho M, et al. (eds): SEER Cancer Statistics Review, 1975-2014, National Cancer Institute. Bethesda,
MD, https://seer.cancer.gov/csr/1975_2014/, based on November 2016 SEER data submission, posted to the SEER web site, April 2017. Accessed September 24, 2017.

36. Miller JW, Smith JL, Ryerson AB, et al. Disparities in breast cancer survival in the United States (2001-2009): Findings from the CONCORD-2 study. Cancer 2017; 123(Suppl 24):5100-18.

37. Menashe I, Anderson WF, Jatoi I, et al. Underlying causes of the black-white racial disparity in breast cancer mortality: a population-based analysis. J Natl Cancer Inst 2009; 101:993-1000.

38. Surveillance, Epidemiology, and End Results Program (SEER). http://seer.cancer.gov/Accessed May 2, 2014.

39. Bland JM, Altman DG. Survival probabilities (the Kaplan-Meier method). BMJ 1998; 317(7172):1572-80.

40. Bellera CA, MacGrogan G, Debled M. Variables with time-varying effects and the Cox model: some statistical concepts illustrated with a prognostic factor study in breast cancer. BMC Medical Research Methodology 2010; 10:20-31.

41. Hess KR. Graphical methods for assessing violations of the proportional hazards assumption in Cox regression. Statistics in Medicine 1995; 14:1707-1723.

42. Ning J, Peng S, Ueno N, et al. Has racial difference in cause-specific death improved in older patients with late-stage breast cancer? Annals of Oncology 2015; 26:2161-8.

43. Dawood S, Broglio K, Gonzalez-Angulo AM, et al. Trends in survival over the past two decades among white and black patients with newly diagnosed stage IV breast cancer. Journal of Clinical Oncology 2008; 26:4891-8.

44. Borger JH, Hooning MJ, Boersma LJ, et al. Cardiotoxic effects of tangential breast irradiation in early breast cancer patients: the role of irradiated heart volume. International Journal of Radiation Oncology, Biology, Physics 2007; 69:1131-8.

45. McGale P, Darby SC, Hall P, et al. Incidence of heart disease in 35,000 women treated with radiotherapy for breast cancer in Denmark and Sweden. Radiotherapy \& Oncology 2011; 100:167-75.

46. Henson KE, McGale P, Taylor C, et al. Radiation-related mortality from heart disease and lung cancer more than 20 years after radiotherapy for breast cancer. British Journal of Cancer 2013; 108:179-82.

47. Owusu C, Lash TL, Silliman RA. Effect of undertreatment on the disparity in age-related breast cancer-specific survival among older women. Breast Cancer Research \& Treatment 2007; 102:227-36.

48. Schwentner L, Wockel A, Konig J, et al. Brenda study group. Adherence to treatment guidelines and survival in triple-negative breast cancer: a retrospective multi-center cohort study with 9,156 patients. BMC Cancer 2013; 13:487.

49. Hamaker ME, Bastiaannet E, Evers D, et al. Omission of surgery in elderly patients with early stage breast cancer. European Journal of Cancer 2013; 49:545-52.

50. Grumpelt AM, Ignatov A, Tchaikovski $\mathrm{SN}$, et al. Tumor characteristics and therapy of elderly patients with breast cancer. Journal of Cancer Research \& Clinical Oncology 2016; 142:1109-16.

51. Dialla PO, Dabakuyo TS, Marilier S, et al. Population-based study of breast cancer in older women: prognostic factors of relative survival and predictors of treatment. BMC Cancer 2012;12:472.

52. Bickell NA, Weidmann J, Fei K, et al. Underuse of breast cancer adjuvant treatment: patient knowledge, beliefs, and medical mistrust. Journal of Clinical Oncology 2009; 27:5160-7.

53. McCaskill-Stevens W, McKinney MM, Whitman CG, et al. Increasing minority participation in cancer clinical trials: The Minority-Based Community Clinical Oncology Program experience. J Clin Oncol 2005; 23:5247-54.

54. Wieder R, Teal R, Saunders T, et al. Establishing a Minority-Based Community Clinical Oncology Program: The University of Medicine and Dentistry of New Jersey, New Jersey Medical School-University Hospital Cancer Center Experience. J Oncology Practice 2013; 9:e48-54.

55. Keenan T, Moy B, Mroz EA, et al. Comparison of the Genomic Landscape Between Primary Breast Cancer in African American Versus White Women and the Association of Racial Differences With Tumor Recurrence. Journal of Clinical Oncology 2015; 33:3621-7.

56. Ademuyiwa FO, Tao Y, Luo J, et al. Differences in the mutational landscape of triple-negative breast cancer in African Americans and Caucasians. Breast Cancer Research \& Treatment 2017; 161:491-9. 
57. Conway K, Edmiston SN, Tse CK, et al. Racial variation in breast tumor promoter methylation in the Carolina Breast Cancer Study. Cancer Epidemiology, Biomarkers \& Prevention 2015; 24:921-30.

58. Dietze EC, Sistrunk C, Miranda-Carboni G, et al. Triple-negative breast cancer in African-American women: disparities versus biology. Nature Reviews Cancer 2015; 15:248-54.

59. Chandler MR, Keene KS, Tuomela JM, et al. Lower frequency of TLR9 variant associated with protection from breast cancer among African Americans. PLoS ONE 2017; 12:e0183832. 